\title{
The Role of University on the Civic Preparation of the Youth
}

\author{
Lindita Lutaj \\ PhD, University “Aleksander Moisiu”, Durres, \\ Faculty of Education, Department of Pedagogy, Albania
}

\begin{abstract}
University plays an important role in equipping students with knowledge and academic expressions. The institution helps the students in development of society understanding and civil engagement. The aim of this study is to observe the role of university through the curricula in civil preparation of the students and their awareness for active civic participation. The study used a mix quantitative and qualitative scientific method. The instrument included online closed and open questions, which were completed from 50 second year students, of Education Faculty, Professional Master "Elementary Education Teacher" and Professional Master of "Didactics". The study resulted that students are very interested in being prepared in Democratic Civil Education. Practical activity is very important, but the pandemic was an obstacle in performing practical activities. Students state that using convincing argument, preparation job and researching the information from various sources helps them develop high-level thinking, and reach high results. Family civil education also helps them in continuing further education. Students gain knowledge, skills, attitudes and values from the university as prerequisites to be active future citizens. Realizing the teaching quality indicators in university is necessary for youth healthy democratic formation. It is important to increase students' awareness and motivation for change. This is to make them aware in fulfilling their mission on creating a democratic civil society, with responsible citizens for their roles and engagement taken. Universities should know their responsibilities by including in the Education Faculty programs the curricula of Civil Education to increase students' academic and create practical expressions.
\end{abstract}

Keywords: civil education, participation, practical activities, active citizenship

\section{Introduction}

Civic education equips people with knowledge, skills and expressions in order to actively participate and to be aware in society, as critical citizens who take their responsibilities in a very serious matter. Each society needs people who contribute effectively for a healthy and consistent community.

The youth should be aware that by acquiring values and human principles, wherever they come from; university programs, family or society, in the future they will facilitate the problems that challenge their lives. An education in the area of civilization cannot be though to be a closed process, but it should be an open program, which lives only out of the auditorium areas. Students need to be skilled on problem solving methods, to show tolerance and 
understanding of the individuals that think differently, and know how to compromise in order to achieve cooperation. In the developed countries, many programs are developed in order to prioritize in the curricula of the civic development the processes that include the responsibility taking, cooperation, tolerance, compromise, development of skills of feeling expression, conflict resolutions, moral values acquisition etc.. These education programs have created a high feeling of responsibility and altruist behavior for the students. Without a wide active civil participation, the democracy starts to be vanished, underestimated, and become solely defensive of a vicious cycle of people. With the active participation of people of all societies, the democracy will withstand the inevitable storms of various groups.

Universities are academic institutions that are obliged to transmit knowledge, values and behaviors to the young generation, things that are important for development of the moral dimension of an individual, political stability, economic wellbeing, and cultural continuance of the community. The mission of universities is to create a cooperation climate, understanding, tolerance, partnership and equal opportunities for all students. The mission aims to develop the personality, preparation of the students as citizens with full rights to act independently.

Organization of activities should be the main part of the university programs as it enables the students to be initiators, to be more cooperative in helping the community. A very important requirement of participation is the tendency of the students to be active in the problems of the community, which is directly related to the rights and responsibilities of each individual in consolidating a healthy democratic system. A strong supportive point of view for the students should be the pedagogues, who contribute in encouragement and counseling. Education in democratic citizenship goes further than the area of the auditorium, challenging the division between the formal and informal education, the qualitative improvement of academic levels, acquiring the civic competencies so necessary for the social changes.

Including the elements of civic democratic education in the curricula of the programs in the Pedagogy Department in the Faculty of Education is considered with priority and has aimed to prepare professionals who are ready for the job market and to be successful as teachers. In the bachelor system, the actual curriculum creates possibility to recognize the civil democratic education concepts through the course of "Education with the rights of children and civic education". Through this module the student teachers are presented with the knowledge of rights, institutions, their history and the support of the students during the creation of their personality. The students are aware of the rule respect in community, the values that they should possess, the importance of tolerance, understanding, compromise, collaboration, the way to confront the conflicts and to find the ways of problem solving, to argument the importance of being a citizen in classroom, school and community. In the master level, the module of "Democratic Civic Education" helps the students to gain deeper knowledge in order to know the factors that necessitate the competencies in civil education, standards, curriculum, principles, objectives etc..

\section{Theoretical background}

According to Gora. C (2007) "Civic Democratic Education is an indicator of the development of the education quality of a country, is a strong point of support for the social development and adherence in EU".

European societies change from each other from the number and the degree of the complexity of the conditions and education services that they offer for the learning process of the civic education and for the relations between the education results and their social recognition. 
Emphasizing only the individual responsibility may bring undesirable consequences, particularly when this happens in societies in transition where choices of selection in education areas and the relations between the education and its social acceptance are rare. In such situations where the odds for independent choices do not exit, the individual becomes less aware on the learning aspect. This is the reason that the mutual responsibility of the individual and society keeps the main place in the learning aspect for the democratic civilization during the lifetime states the Council for Cultural Collaboration (2000).

The council conclusions in May 2009 expressed that "One of the main objectives of the Strategic Model for European Collaboration in the education area and training till 2020 is the promotion of the cohesion, social capital and the active citizenship through education as Vassiliou. A reported in 2009 also".

"The key to be responsible in a modern society is to take responsibility for your own life, this is a virtue of independence and autonomy. Independence of the judgement as necessary as the autonomy of acting. The individual should be left to create his own opinions is stated in Civic Education for Europe". In the Card of EDC is recommended that education for a democratic citizenship is mainly focused on the democratic rights and responsibilities and the active participation in the civic, political, social, economic, legal and cultural areas of society ...".

Civic democratic education includes a set of concepts and basic values, which are common for all modern democracies. The democratic principles are universal, but their implementation is realized in accordance to the actual circumstances of each society, that is why the students are prepared to live as citizens of a democratic society. The Ministers Committee recommended in 2010 that member states should support the involvement of education for a democratic society and for the human rights in the institutions of higher education, especially the ones that prepare future teachers by respecting the principle of academic freedom of these institutions.

The role of university in training and certification of the teachers and the insurance of the teaching quality has a very high importance states Gora C, (2007). In Austria, 'master' programs in civic education organized by various universities, especially the university of Strasburg (2011) are available for teachers of all subjects and schools. Vassiliou A, (2012) stated that they are designed to support the teachers in implementing the civic education in the most effective way possible, within their specialty and/or the fundamental principles of civic education.

Alma Powell, Alliance of American Promise emphasizes: "When the youth discover that they can be the agents of change, miracles happen. They start to serve in neighborhoods, learn public affairs, create innovative solutions for difficult public challenges and finally become voters, builders of community projects and leaders of our communities and nations. The center of this transformation from spectator to citizen means that who we are as Americans, our main democratic values and individual roles we can play. Guardian of Democracy in 2003 wrote that american history and civic education should be the main focus of public education for each school in America.

Chris Waller, Society for Citizenship Teaching in 2006 states that the specialists of citizenship are extraordinary assets for the school, and the schools know that, but more often they hire them in a context far from citizenship. More often, this makes the new qualified teachers to be delusional and quitting the profession all together. One of the main objectives stated in the European Strategy for the Youth 2010-2018 is the promotion of the active citizenship, social 
participation, and solidarity of all the young people. "Vassiliou A, in 2012 said that there were two main events in 2011, the year 2011 was declared the European Year of Voluntary Activity, the promotion of active citizenship and the Hungarian presidency selected the civil education as the main theme of the debate between the education ministers during an informal meeting held in March.

Civil citizenship is a main issue in the Lisbon program. The European Commission promoted three big pillars and one of them is "teaching an active citizenship". In the detailed program of working for following the education system and training in Europe, The EU has developed 13 objectives related to the Lisbon program, the objective 2.3 relates to: "Support for active citizenship, equal opportunities and social cohesion". Among issues mentioned earlier in the work program related to the active citizenship are "to ensure that learning democratic values and participation from all is promoted effectively to prepare individuals for an active citizenship according to De Weerd at al, 2005 ". Guomundur Heioar Frimannsson asks if we should allow the youth to develop these skills they want and create interests they like.

\section{Stating the problem and the goals of the study}

University programs in the civic area serve the students to know the factors that make Democratic Civic Education a necessity, as the main pillar of the democratic society. Students know the importance of recognizing and respecting the human identity in a democratic society. Through these classes the students are equipped with the theoretical basis and practical expressions to argument why is it important to take responsibilities in a democratic society, to understand the importance of knowing the laws and rules, and their implementation in the living community. Students are prepared to know conflicts, management and resolutions in society.

The goal of this study is to evaluate the role that the universities play in promoting the active citizenship in youth groups through curricula, in the university programs of Education Faculties, that prepare teachers, and the challenges that this university education system faces in this pandemic situation.

Objectives consist on studying the impact of the university programs of the youth with active citizenship, based on various national and international programs, curricula modules and development of an online questionnaire with the students of teaching program. Objectives consist on knowing the importance of civil education of the youth as one of the main pillars of the democratic society, in promoting the civil values of future teachers, who will educate generations of students through professionalization and dedication.

The study used the contemporary pedagogic literature related to the impact of the role of the university programs on the active participation of the youth and the importance that this participation has on the democratic development of the country. The quality level of the education process needs to be raised through the development of civic competency, as a necessary value for the formation of the future teachers, by better using the youth potential and their contribution for the best of their living community.

\section{Methodology}

The study used the quantitative method through completing an online questionnaire $(\mathrm{N}=50)$ together with the qualitative research realized through the focus group $(\mathrm{N}=20)$ made of students. 
The study instrument included open and closed questions, completed online from the participating students. The sample included second year students of the Education Faculty, University "Aleksander Moisiu" Durres, program of Professional Master "Elementary Education Teacher" and Professional Master "Didactics". 92\% of the sample were females and $8 \%$ males, as these types programs have mostly female students. $88 \%$ of the participants had 0-3 years of work experience, $6 \%$ had $4-10$ years, $2 \%$ had $10-20$ years and $4 \%$ over 20 years.

The hypothesis of the study is "Facing the pandemic is a challenge for the promotion of the active citizenship in youth of universities", and to prove it we raised the following research questions:

What are the priorities that the university programs bring in the area of citizenship to increase the youth active participation?

What are the difficulties that the students faced during promotion of the active citizenship out of the auditorium?

What are the challenges of promoting the active citizenship of the youth in consolidating a democratic society?

\section{Results and discussion}

The participating students completed the online questionnaire by expressing their opinions and behaviors. They were asked if the university has all the conditions to organize the practical activities in the area of Democratic Civic Education. 18\% stated that they totally agreed, so the university fulfills the conditions. $44 \%$ agreed, $12 \%$ were neutral, $24 \%$ somewhat agreed and $2 \%$ did not agree.

When asked if the environment around the university enables the development of out of auditorium activities, $16 \%$ stated that they totally agreed they had the proper environment, $42 \%$ agreed, $22 \%$ were neutral, $12 \%$ somewhat agreed and $8 \%$ did not agree. In relation to the opportunities that the environment offers within the university, for the organization and demonstration of the practical activities of the students, $34 \%$ of them totally agreed that were offered a proper environment, 48\% agreed, $8 \%$ were neutral and $10 \%$ somewhat agreed.

The students' answers showed that the university enables them to organize practical activities in the environments inside and outside the auditorium. Regarding this issue, there is still room for improvement, there is a considerable number of students who do not speak out, but remain neutral.

When students were asked if they were interested in gaining knowledge in the field of Democratic Civic Education, 80\% strongly agreed, 10\% agreed, 2\% remained neutral, 6\% somewhat agreed and $2 \%$ did not agree at all. So about $90 \%$ of students say that they are interested in obtaining knowledge in the field of DCE and consider it very important to acquire knowledge in the field of citizenship, while $88 \%$ of participants stated that courses they take in school enable them to organize practical activities. They state that receiving information in this area enables them to prepare themselves academically and practically for participation and decision-making in their community.

When asked if the pandemic situation made it difficult for them to practice, $60 \%$ strongly agreed that it was difficult for them, 26\% said that they agreed, $4 \%$ remained neutral, $8 \%$ partially agreed and $2 \%$ did not agree at all. So, $86 \%$ of students see the pandemic as an obstacle in carrying out concrete activities to help the community, as active citizens. Regarding the question how much the civic education they received in their family helps them in their 
further civic formation, $76 \%$ of them strongly agreed that the education they received helped them, $18 \%$ agreed, $4 \%$ remained neutral, and $2 \%$ did not agree at all. About $52 \%$ of students said that organizing practical activities to help the community is difficult, $26 \%$ of them did not express an opinion and $22 \%$ stated it is somewhat difficult.

The problems caused by the pandemic situation were felt on the practical training of the students, in the absence of the organization of activities and real actions in and out of the university environment. During the previous years there were excellent experiences on the activities organized by the students helping the people in need. Such an activity was the one performed on June 22, 2017 "Citizenship and youth involvement in civic actions, a necessity for the democratic development in the country" where participated around 100 students who presented their studies, and later on continued with the charitable activities for the orphans in the orphanage of Shkozet, Durres. (https://durreslajm.al/aktualitet/uamd-aktiviteteshkencore-dhe-bamiresi-jetimet-video).

The following year, June 23, 2018 the tradition continued with visits to the Nursing Home in Kavaje, where old people and young students created a celebrating environment. This activity included 130 students who offered their services to the elders and brought gifts. These types of activities are greatly appreciated from the students and they gladly organize them. When the students were asked that how much the programs in the field of citizenship help them in overcoming the difficulties, $26 \%$ of them said that they strongly agreed that this opportunity was created for them, $48 \%$ agreed, $6 \%$ remained neutral and $20 \%$ partially agreed. Students were asked to express how prepared they were for taking on roles and responsibilities in school and community, 32\% strongly agreed of being ready, $48 \%$ agreed, $8 \%$ remained neutral, $10 \%$ somewhat agreed and $2 \%$ did not agree at all. Analyzing the answers, about 70 $80 \%$ of students admit that the university prepares them in practical training to solve the problems faced, as well as in taking responsibility in society. Regarding the question if the students possess the competencies in the field of citizenship, so necessary for a democratic society, $46 \%$ strongly agreed, $38 \%$ agreed, $14 \%$ remained neutral and $2 \%$ somewhat agreed. So, $84 \%$ of students think that the university prepares them with the necessary civic competencies.

\section{Conclusions}

The curricular framework in the field of civic education supports national standards of educational development, provides flexibility in teaching, guarantees the necessary space for active and interactive learning. In our reality the study showed that there is still work needed to improve the quality indicators in terms of active student participation. This can be seen in the answers given by the students on their strengths and weaknesses regarding their active participation. Thus in the strong points they list the desire to express free thought, selfdemands on improvement, the will to achieve what they want, the responsibility they feel towards others, being cooperative, accepting ideas and thinking differently, knowing the laws and responsibility for idea implementation, information about the issues of society, participation in conferences on the protection of human rights and citizenship, the desire to have a better community, etc.

As for the difficulties they face and which do not enable them to exercise active citizenship, they list the impossibility in time, lack of information on various issues, lack of motivation, family commitments, disappointment they have suffered in many cases, fear of pressure from others, lack of civic organization, financial difficulties, non-compliance with rules, limited number of activities, lack of free speech prevents them to be themselves, the inherited way of 
thinking, indifference, frustration and distrust of the people they lead, etc. Students seek a collaborative climate, positive and more open communication with the whole community in terms of organizing activities at DCE, as this not only reinforces their knowledge but transforms that knowledge into habits and values, making them part of each student's personality. Work forms that promote the active participation of students are needed to be used, as they are promoters of free speech, who know how to take responsibility. Indifference and lack of cooperation between many different actors makes it difficult to achieve the desired results in the field of citizenship. It is important that in working with students are used problem situations from everyday life, in the thematic treatment of DCE classes. In addition to theoretical information, it is important for the students to practice by becoming more closely acquainted with the problems and possible solutions, challenges and how to overcome them.

The pedagogues should consider the combination of theory with practice, and the lecture hours to be performed not only within the faculty environment, but also out of the auditorium and the university premises. This will help the students to know more places, to get further information for the topics treated in the lectures, to know better the issues of society, how the institutions function. This knowledge will make the students more sensible and more responsible as individuals.

It is of a special importance for the university to collaborate with all the actors, citizens, local government and non-governmental organizations all over the country. Each student should have the possibility to express personal opinion as they like, without fear and embarrassment, as this is the right way for them to become active citizens of the future.

The universities' moto is the organization of many activities with students, increasing the trust to self- development and to critically think the social issues. The collaboration between pedagogues and students and interaction between students among themselves creates the possibility to take on responsibility and to resolve confronted issues.

It is also important to train, qualify and self-training for students, who are the teachers of the future, in order to improve their professional formation.

Familiarizing students with their rights and responsibilities helps them to improve their behavior, to equip them with civic competencies, necessary for a democratic society. DCE learning creates opportunities for active citizenship, creates the necessary framework for living in modern multicultural societies, and makes each individual feel valued and independent in the acquisition of civic values and behaviors. It is very important to include civic education and training curricula in the university programs of teaching faculties, as they enable the academic training of student teachers of all branches, so necessary for a society aspiring to democracy. All teachers confront students in situations that require their commitment and dedication, so they must be prepared to face these situations, in order to prepare the younger generations as worthy citizens of Europe and the whole world. Universities need to know their responsibilities for the teachers they train, in order to increase the quality level of preparation in the area of DCE, to meet the challenges that the actual time demands today.

\section{References}

[1] Civic Education in Europe, (2000). Same General Principles. University Boon.

[2] Conclusioni del Consiglio (2009) Su un quadro strategico per la cooperazione europea nel settore dell'istruzione e della formazione ('ET 2020'), OJ C 119 
[3] Corporation for National \& Community Service, (2006). Youth Helping America, Educating for Active Citizenship, Service - Learning, School - Based Service, and Youth Civic Engagement, pg. 43.

[4] Council for Cultural Cooperation (KBK/CDCC), Strategy on learning of civilization

[5] Dautaj, A. , (2003). Curricula and school, Philosophy and civil education, Institute of Pedagogic Studies. Tirana,.

[6] De Weerd, M. , Gemmeke,M., Rigter,J., Van Rij, C., (2005). Indicators for Monitoring Active Citizenship and Citizenship Education, Amsterdam, pg. 7.

[7] Decisione del Consiglio (2009). Su un quadro rinnovato di cooperazione europea in materia di gioventù (2010-2018), OJ C311, [pdf]. Disponibile all'indirizzo: Strasburg, 2000 , pg. 19.

[8] del Consiglio del 12 maggio 2009 su un quadro strategico per la cooperazione europea nel

[9] Gora, C., Gore, V., Skolstvo, Z., (2007), Strategy for Civic Education in Primary and Secondary School in Montenegro 2007-2010, Unicef and the NGO Centre for Civic Education, pg. 32.

[10] Gora, C., Gore, V., Skolstvo, Z., (2007). Strategy for Civic Education in Primary and Secondary School in Montenegro 2007-2010, Unicef and the NGO Centre for Civic Education, pg. 14.

[11] Guomundur Heioar Frimannsson, (2000). Civic Education in Europe: Some General Principles, pg. 7.

[12] http://ec.europa.eu/youth/pdf/doc1648_en.pdf [Disponibile dal 7 Maggio 2012]

[13] Master di studi politici e cittadinanza democratica (2011) (Università di Salisburgo in collaborazione con l'Università dell'educazione di Salisburgo e la Fachhochschule di Salisburgo, Università di scienze applicate)

[14] Recommendations CM/Rec (2010). 7 of the Ministers' Council for member states for the Card of Education for Democratic Civilization and Education for Human Rights of the EC. Approved by the Ministers' Committee, May 11 th $2010,120^{\text {th }}$ session. pg.7

[15] Report, Guardian of Democracy. (2003). The Civic Mission of Schools in partnership with the Educating for Democracy, University of Pennsylvania, Division for Public Education, National Conference on Citizenship, pg.24.

[16] settore dell'istruzione e della formazione ('ET 2020'), OJ C 119.

[17] The card of EDC, Recommendations CM/Rec (2010). 7 of the Ministers' Council, Card of the European Council for Education of a Democratic Civilization and for the Human Rights, pg.7.

[18] Vassiliou, A., (2009). L'educazione alla cittadinanza in Europa, pg. 3, Eurydice report, Conclusioni

[19] Vassiliou, A., (2012). L'educazione alla cittadinanza in Europa, EuryDice, pg. 7.

[20] Vassiliou, A., (2012). L'educazione alla cittadinanza in Europa, EuryDice, pg.90. 